\title{
Davis Buckley Hyper Immunoglobulin E Syndrome Associated with IgA deficiency: The second Case
}

\author{
Aamir Jalal Al Mosawi* \\ Advisor doctor and expert trainer, Baghdad Medical City and the National Center of Training and Development, Head, Iraq \\ Headquarter of Copernicus Scientists International Panel, Baghdad, Iraq
}

*Corresponding author: Aamir Jalal Al Mosawi, Advisor doctor and expert trainer, Baghdad Medical City and the National Center of

Training and Development, Head, Iraq Headquarter of Copernicus Scientists International Panel, Baghdad, Iraq

ARTICLE INFO
Received: 㓞 November 10, 2020
Published: 㓞 November 19, 2020

Citation: Aamir Jalal Al Mosawi. Davis Buckley Hyper Immunoglobulin E Syndrome Associated with IgA deficiency: The second Case. Biomed J Sci \& Tech Res 32(1)-2020. BJSTR. MS.ID.005185.

Keywords: Davis Buckley Syndrome; Hyper Immunoglobulin E (IgE); Recurrent Infection Syndromes; IgA Deficiency

\section{ABSTRACT}

Background: Davis Buckley hyper immunoglobulin E (IgE) recurrent infection syndromes are very rare group of heterogeneous disorders of variable genetic basis and manifestations, but they are essentially characterized by significant elevation of serum IgE levels occurring in association with recurrent infections with or without coarse facial features and eosinophilia. The aim of this paper is to report the occurrence of an extraordinary case of Davis Buckley syndrome associated with associated with IgA deficiency.

Patients and Methods: An Iraqi boy of Turkish origins was referred at the age of 10 years to the pediatric psychiatry clinic at the Children Teaching Hospital of Baghdad Medical City because of poor school performance and poor attention span was studied.

Results: The boy didn't have coarse facial features or facial dysmorphism. During the previous few years the boy was experiencing urinary tract infections and recurrent ear infections associated with discharge and were being treated with several courses of antibiotics. The boy didn't have growth retardation or bony or dental abnormalities. The parents were health relative, and family history was negative for similar condition. Blood tests showed eosinophilia and reactive thrombocytosis. Serum IgE was significantly elevated at the level of $0.4 \mathrm{mg} / \mathrm{dL}$ (normal $0.01-0.04 \mathrm{mg} / \mathrm{dL}$ ). The patient also had very low IgA level which was $18 \mathrm{mg} / \mathrm{dL}$ (normal 90-450 mg/dL). Mutation analysis was positive for Stat 3 mutation.

Conclusion: There has been only one case of Davis Buckley syndrome associated with low IgA levels reported by Mazzone et al (1996). The case in this paper is most probably the second case of the syndrome associated with IgA deficiency.

\section{Short Communication}

Davis Buckley hyper immunoglobulin E (IgE) recurrent infection syndromes are very rare group of heterogeneous disorders of variable genetic basis and manifestations, but they are essentially characterized by significant elevation of serum IgE levels occurring in association with recurrent infections with or without coarse facial features and eosinophilia. The syndrome may also be associated with eczema, skeletal and dental abnormalities [1-4]. In 1966, Davis et al described two red-haired, fair-skinned girls who had infection sino-pulmonary, staphylococcal cutaneous infections, Elevated levels of IgE and defective of neutrophil chemo taxis. Davis et al thought that the condition could be similar to the affliction of
Job, a biblical prophet whose body was covered with sore boils [1]. Buckley [2] described two boys had severe dermatitis, recurrent cutaneous, pulmonary, joint abscesses, growth retardation, and coarse facial features. The boys also had with significant elevation serum IgE levels and eosinophilia [2]. The aim of this paper is to report the occurrence of an extraordinary case of Davis Buckley syndrome associated with associated with IgA deficiency.

\section{Patients and Methods}

An Iraqi boy of Turkish origins was referred at the age of 10 years to the pediatric psychiatry clinic at the Children Teaching Hospital 
of Baghdad Medical City because of poor school performance and poor attention span was studied.

\section{Results}

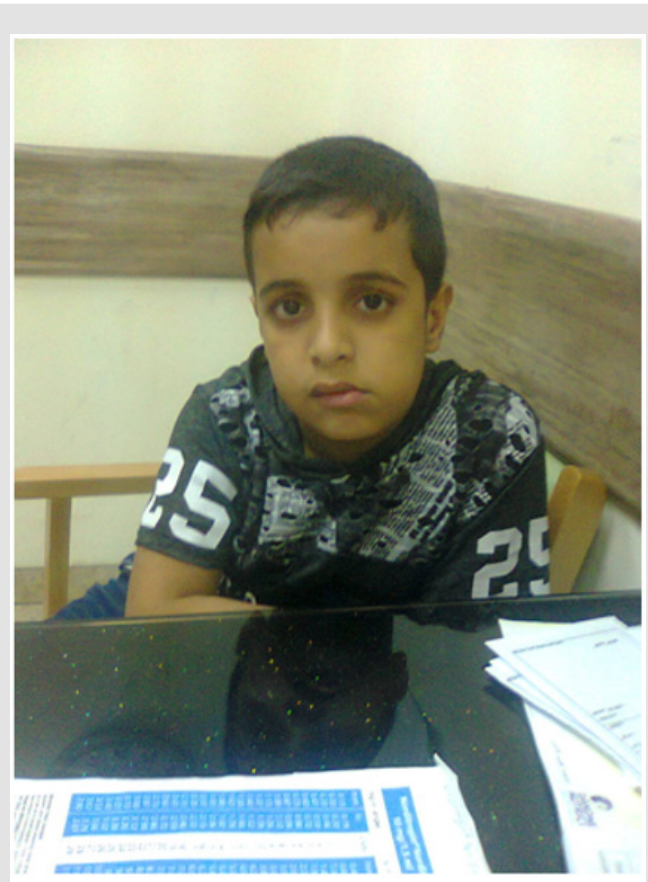

Figure 1: The boy didn't have coarse facial features or facial dysmorphism.

Table 1.

\begin{tabular}{|c|c|}
\hline ESR & $22 \mathrm{~mm} / \mathrm{hour}$ \\
\hline Hemoglobin & $12.6 \mathrm{~g} / \mathrm{dL}$ \\
\hline Hematocrit (HCT) & $35.1 \%$ \\
\hline WBC & $7.99 \times 10^{9} / \mathrm{L}$ \\
\hline Neutrophil & $2.07(36.3 \%)$ \\
\hline Lymphocyte & $3.95(52.4 \%) \%$ \\
\hline Monocyte & $.471(6.24 \%)$ \\
\hline Eosinophil & $.344(4.55 \%)$ \\
\hline Basophile & $.111(1.47 \%)$ \\
\hline $\mathrm{RBC}$ & $4.58 \times 10^{12} / \mathrm{L}$ \\
\hline Mean corpuscular volume (MCV) & $76.5 \mathrm{FL}$ \\
\hline Mean corpuscular hemoglobin $(\mathrm{MCH})$ & $28.2 \mathrm{pg}$ \\
\hline $\begin{array}{l}\text { Mean corpuscular hemoglobin } \\
\text { concentration (MCHC) }\end{array}$ & $30.0 \mathrm{~g} / \mathrm{dL}$ \\
\hline Red blood cell distribution width (RDW) & $13.1 \%$ \\
\hline Platelet count & $619 \times 10^{9} / \mathrm{L}$ \\
\hline Mean platelet volume (MPV) & $4.99 \mathrm{FL}$ \\
\hline
\end{tabular}

The boy didn't have coarse facial features or facial dysmorphism (Figure 1). During the previous few years the boy was experiencing urinary tract infections and recurrent ear infections associated with discharge and were being treated with several courses of antibiotics. The boy didn't have growth retardation or bony or dental abnormalities. The parents were health relative, and family history was negative for similar condition. Blood tests showed eosinophilia and reactive thrombocytosis (Table 1). Serum IgE was significantly elevated at the level of $0.4 \mathrm{mg} / \mathrm{dL}$ (normal $0.01-0.04$ $\mathrm{mg} / \mathrm{dL}$ ). IgG level was $1065 \mathrm{mg} / \mathrm{dL}$ (normal 800-1800 mg/dL), and IgM level was $144 \mathrm{mg} / \mathrm{dL}$ (normal $60-180 \mathrm{mg} / \mathrm{dL}$ ). The patient also had very low IgA level which was $18 \mathrm{mg} / \mathrm{dL}$ (normal 90-450 mg/ $\mathrm{dL}$ ). Mutation analysis was positive for Stat 3 mutation.

\section{Discussion}

Szczawinska Poplonyk [4] emphasized the complexity of the syndrome, the diversity of clinical manifestations, and the heterogeneous genetic nature. They suggested the possibility of the existence of an autosomal dominant classical form of the syndrome, and an autosomal recessive form. The autosomal dominant hyper-IgE syndrome is associated with facial, dental, skeletal, and connective tissue abnormalities which are not reported in association with the recessive type [4]. During childhood, platelet counts range between 250 x 109/L and x 109/L. An elevated platelet count more than 500, 000109/L indicates the presence of thrombocytosis. Primary thrombocytosis is an extremely rare during childhood, while secondary or reactive thrombocytosis is commonly a reactive process caused by infection, chronic inflammation, and iron deficiency [5]. The dominant form Davis Buckley syndrome has generally been attributed to STAT-3 mutation with loss of function of the signal transducer and activator of transcription 3, while autosomal recessive forms are generally attributed to mutations in dedicator of cytokines 8 (DOCK-8) [6].

In this case, the occurrence of Davis Buckley syndrome without coarse facial features, but with eosinophilia and the presence of Stat 3 mutation suggest an overlap between the autosomal dominant and recessive forms. Mazzone [7] emphasized the rarity IgA deficiency in association with Davis Buckley syndrome. They reported a young woman with Davis Buckley syndrome who had recurrent urinary tract infectios, genital bacterial infections, generalized erythematous eczematous patches and stomatitis of oral mucosa and fever. The patient had high immunoglobulin IgE and low IgA levels [7].

\section{Conclusion}

There has been only one case of Davis Buckley syndrome associated with low IgA levels reported by Mazzone [7]. The case in this paper is most probably the second case of the syndrome associated with IgA deficiency.

\section{Acknowledgement}

The author would like to acknowledge his for the parents for willing accepting publishing the photo of the child. 


\section{References}

1. Davis SD, Schaller J, Wedgwood RJ (1966) Job's Syndrome. Recurrent, "cold", staphylococcal abscesses. Lancet 1(7445): 1013-1015.

2. Buckley RH, Wray BB, Belmaker EZ (1972) Extreme hyperimmunoglobulinemia $\mathrm{E}$ and undue susceptibility to infection. Pediatrics 49(1): 59-70.

3. Hill HR, Quie PG (1974) Raised serum-IgE levels and defective neutrophil chemotaxis in three children with eczema and recurrent bacterial infections. Lancet 1(7850): 183-187.

4. Szczawinska Poplonyk A, Kycler Z, Pietrucha B, Heropolitanska Pliszka E, Breborowicz A, et al. (2011) The hyperimmunoglobulin E syndrome-

ISSN: 2574-1241

DOI: $10.26717 /$ BJSTR.2020.32.005186

Aamir Jalal Al Mosawi. Biomed J Sci \& Tech Res

(C) (P) This work is licensed under Creative

Submission Link: https://biomedres.us/submit-manuscript.php clinical manifestation diversity in primary immune deficiency. Orphanet J Rare Dis 6: 76.

5. Chiarello P, Magnolia M, Rubino M, Liguori SA, Miniero R (2011) Thrombocytosis in children. Minerva Pediatr 63(6): 507-513.

6. Alcántara Montiel JC, Vega Torres BI (2016) Síndrome hiper-IgE. Lecciones de la función y defectos de STAT-3 o DOCK-8 Rev Alerg Mex 63(4): 385-396.

7. Mazzone A, Girola S, Fossati G, Mazzucchelli I, Ricevuti G (1996) Sindrome di Giobbe (Iper-IgE) ed ipo-IgA. Rara associazione di immunodeficienze. Recenti Prog Med 87(2): 71-74.

$\begin{array}{ll}\text { BIOMEDICAL } & \text { Assets of Publishing with us } \\ \text { RESEARCHES } & \text { - Global archiving of articles } \\ \text { - Immediate, unrestricted online access }\end{array}$

